\title{
Correction: Understanding changes in dyspnoea perception in obstructive lung disease after mindfulness training
}

Malpass A, Feder G, Dodd JW. Understanding changes in dyspnoea perception in obstructive lung disease after mindfulness training. BMJ Open Resp Res 2018;5:e000309. doi: 10.1136/bmjresp-2018-000309

This article has been corrected since it first published. The open access license has been changed to:

This is an open access article distributed in accordance with the terms of the Creative Commons Attribution (CC BY 4.0) license, which permits others to distribute, remix, adapt and build upon this work, for commercial use, provided the original work is properly cited. See: http://creativecommons.org/licenses/by/4.0/

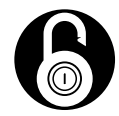

\section{OPEN ACCESS}

Open access This is an Open Access article distributed in accordance with the Creative Commons Attribution 4.0 Unported (CC BY 4.0) license, which permits others to copy, redistribute, remix, transform and build upon this work for any purpose, provided the original work is properly cited, a link to the licence is given, and indication of whether changes were made. See: https://creativecommons.org/licenses/by/4.0/

(C) Author(s) (or their employer(s)) 2018. Re-use permitted under CC BY. Published by BMJ.

BMJ Open Resp Res 2018;5:e000309corr1. doi:10.1136/bmjresp-2018-000309corr1

A) Check for updates 